\title{
MICROSTRUCTURE EVOLUTION AND DAMPING CHARACTERISTICS IN CAST Mg-Al-Si ALLOYS
}

\author{
RAZVOJ MIKROSTRUKTURE IN DUŠILNE LASTNOSTI LITIH \\ Mg-Al-Si ZLITIN
}

\author{
Shuqun Chen ${ }^{1}$, Xuanpu Dong ${ }^{2}$ \\ ${ }^{1}$ Beijing University of Technology, School of Materials Science and Engineering, Chaoyang district, Beijing, 100124, China \\ ${ }^{2}$ Huazhong University of Science and Technology, State Key Laboratory of Materials Processing and Die \& Mould Technology, Wuhan, \\ Hubei, 430074, China \\ dongxp@mail.hust.edu.cn
}

Prejem rokopisa - received: 2017-11-16; sprejem za objavo - accepted for publication: 2018-01-09

doi:10.17222/mit.2017.193

\begin{abstract}
The effects of increasing levels of Si on the microstructure and damping capacities of Mg-Al-Si alloys were investigated. The

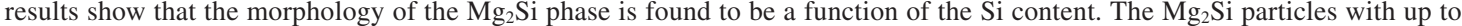
$1.3 \%$ of mass fractions of $\mathrm{Si}$ have a Chinese-script morphology and dendritic $\mathrm{Mg}_{2} \mathrm{Si}$ crystals were precipitated predominantly inside the grains of a $2.3 \%$ of mass fractions of Si-containing alloy. The morphology and volume of the $\mathrm{Mg}_{2} \mathrm{Si}$ phase as well as the distribution of the $\mathrm{Mg}_{17} \mathrm{Al}_{12}$ eutectic have a significant effect on the damping capacity of the alloy. With a low strain amplitude, the dislocation density increases with the formation of $\mathrm{Mg}_{2} \mathrm{Si}$ particles, improving the damping property, while in the high-strain region, dispersed $\mathrm{Mg}_{17} \mathrm{Al}_{12}$ precipitates and coarse $\mathrm{Mg}_{2} \mathrm{Si}$ particles lead to a reduction of the internal friction.

Keywords: $\mathrm{Mg}-\mathrm{Al}-\mathrm{Si}$ alloy, $\mathrm{Mg}_{2} \mathrm{Si}$ morphology, damping capacity, dislocation density
\end{abstract}

V prispevku avtorji opisujejo raziskave vpliva povečevanja dodatka Si na mikrostrukturo in dušilno sposobnost Mg-Al-Si zlitin. Rezultati raziskave so pokazali da je morfologija faze $\mathrm{Mg}_{2} \mathrm{Si}$ odvisna od vsebnosti Si. Delci $\mathrm{Mg}_{2} \mathrm{Si}$ faze imajo pri zlitini z $1.3 \%$ masnih deležev Si obliko kitajskih črk medtem, ko je pri zlitini z $2.3 \%$ masnih deležev Si ta faza izločena v obliki dendritnih kristalov. Morfologija in volumen $\mathrm{Mg}_{2} \mathrm{Si}$ faze, kakor tudi porazdelitev $\mathrm{Mg}_{17} \mathrm{Al}_{12}$ evtektika, ima pomemben vpliv na sposobnost dušenja (vibracij) zlitine. Pri majhnih deformacijskih amplitudah narašča gostota dislokacij s tvorbo $\mathrm{Mg}_{2} \mathrm{Si}$ delcev, $\mathrm{kar}$

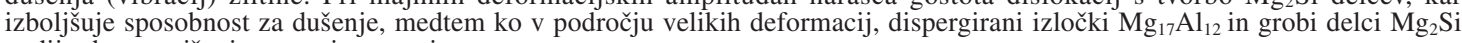
vodijo do zmanjšanja notranjega trenja.

Ključne besede: Mg-Al-Si zlitina, morfologija $\mathrm{Mg}_{2} \mathrm{Si}$, sposobnost za dušenje vibracij, gostota dislokacij

\section{INTRODUCTION}

Conventional approaches to reducing vibration through engineering designs have proved unsatisfactory where size or weight must be minimized or where complex vibrational phenomena exist. Alloys which combine a high damping capacity with good mechanical properties could provide attractive technical and economic solutions to eliminate unwanted noise and vibration. ${ }^{1}$ Pure $\mathrm{Mg}$ exhibits the highest damping capacity, the lowest specific gravity and excellent machining among various metallic materials. ${ }^{2}$ However, its poor mechanical properties, especially at elevated temperature, have rendered it unsuitable for many structural applications. ${ }^{3}$ $\mathrm{Si}$ is considered as an important alloying element for $\mathrm{Mg}$ alloys as the stable $\mathrm{Mg}_{2} \mathrm{Si}$ intermetallic exhibits a low density, a high melting point, a low thermal expansion coefficient (TEC) and a reasonably high elastic modulus. ${ }^{4,5}$ In addition, the low solubility of $\mathrm{Si}$ in $\mathrm{Mg}$ could guarantee free movement of the dislocations segments. The great difference in TECs between $\mathrm{Mg}_{2} \mathrm{Si}$ and the $\alpha-\mathrm{Mg}$ matrix can accelerate dislocation reproduction, which is helpful for improving the damping capacity. ${ }^{6,7}$ The morphology of the $\mathrm{Mg}_{2} \mathrm{Si}$ phase has been found to be critical to the mechanical properties of Si-containing
$\mathrm{Mg}$ alloys from a previous analysis, ${ }^{8}$ but research on the effect of the $\mathrm{Mg}_{2} \mathrm{Si}$ morphology on the damping capacity has rarely been undertaken. ${ }^{9}$ The purpose of the present investigation is to provide a better understanding of Si-containing damping $\mathrm{Mg}$ alloys. In this paper the damping characteristics of $\mathrm{Mg}-\mathrm{Al}-\mathrm{Si}$ alloys are interpreted as functions of the sample microstructure with an emphasis on the effect of the $\mathrm{Mg}_{2} \mathrm{Si}$ morphology and volume on the dislocation density.

\section{EXPERIMENTAL PART}

Table 1 shows the chemical compositions of the investigated alloys in this paper. The specimens were prepared by melting high-purity pure $\mathrm{Mg}, \mathrm{Al}(99.99 \%)$ and $\mathrm{Mg}-25 \% \mathrm{Si}$ (mass fractions) master alloys at $780{ }^{\circ} \mathrm{C}$, under a mixed $\mathrm{CO}_{2}(99 \%)$ and $\mathrm{SF}_{6}(1 \%)$ (volume fractions) protective atmosphere. After adequate stirring and holding for $15 \mathrm{~min}$ at $800{ }^{\circ} \mathrm{C}$, the melt was poured into a preheated steel mould and allowed to cool in air. The phase constitutions were identified by an X'pert PRO X-ray diffraction (XRD) using $\mathrm{Cu}-K_{\alpha}$ radiation. The microstructures were characterized using a Quanta200 and JSM-7600F scanning electron micro- 
scope (SEM). A Tecnai G2 20 transmission electron microscope (TEM) was utilized to observe the dislocation configurations. Strain-dependent damping tests were conducted on a TA Q800 dynamic mechanical analyser (DMA) at various maximum strains from $1 \times$ $10^{-5}$ to $1 \times 10^{-3}$ at room temperature with a constant frequency of $1 \mathrm{~Hz}$. The testing mode uses a single cantilever deformation mode, and the gauge dimension of the damping tests specimen was $40 \mathrm{~mm} \times 5 \mathrm{~mm} \times$ $1 \mathrm{~mm}$.

Table 1: Nominal compositions of investigated alloys

\begin{tabular}{|c|c|}
\hline Alloy No. & Composition \\
\hline 1 & Mg-9\% $\mathrm{Al}-0.3 \% \mathrm{Si}$ \\
\hline 2 & $\mathrm{Mg}-9 \% \mathrm{Al}-1.3 \% \mathrm{Si}$ \\
\hline 3 & $\mathrm{Mg}-9 \% \mathrm{Al}-2.3 \% \mathrm{Si}$ \\
\hline
\end{tabular}

\section{RESULTS AND DISCUSSION}

The XRD patterns of the studied Mg-Al-Si alloys are shown in Figure 1. It is clear that the main phases of the $\mathrm{Mg}$-Al-Si alloys are $\alpha$-Mg, $\mathrm{Mg}_{17} \mathrm{Al}_{12}$ and $\mathrm{Mg}_{2} \mathrm{Si}$. When the level of $\mathrm{Si}$ addition is low, it is difficult to observe $\mathrm{Mg}_{2} \mathrm{Si}$ peaks since the strongest $\mathrm{Mg}_{2} \mathrm{Si}$ peaks overlap with the $\alpha-\mathrm{Mg}$ and $\mathrm{Mg}_{17} \mathrm{~A}_{12}$. With an increase of the Si content, the relative intensity of the $\mathrm{Mg}_{2} \mathrm{Si}$ peaks increase and some peaks can be observed.

Figure 2 shows the microstructure of $\mathrm{Mg}-\mathrm{Al}-\mathrm{Si}$ alloys with different $\mathrm{Si}$ contents. In the Mg-9 \% Al-0.3 $\% \mathrm{Si}$ alloy, a certain fine Chinese-script $\mathrm{Mg}_{2} \mathrm{Si}$ eutectic appears in addition to the massive divorced $\mathrm{Mg}_{17} \mathrm{Al}_{12}$ particles. Figure $2 \mathbf{b}$ explicitly highlights the small $\mathrm{Mg}_{2} \mathrm{Si}$ Chinese script phase and the dimension of the particle is estimated to be $15 \mu \mathrm{m} \times 20 \mu \mathrm{m}$. The EDS results of the corresponding areas in Figure 2b further verify the existence of the $\mathrm{Mg}_{2} \mathrm{Si}$ and $\mathrm{Mg}_{17} \mathrm{Al}_{12}$ phases in the $\mathrm{Mg}-\mathrm{Al}-\mathrm{Si}$ alloy. The microstructure of the $1.3 \%$ Si-containing Mg-9 \% Al alloy is shown in Figure 2e, coarse Chinese-script-shaped $\mathrm{Mg}_{2} \mathrm{Si}$ eutectics can be obviously detected and $\mathrm{Mg}_{17} \mathrm{Al}_{12}$ phase distributes at the interdendritic regions of $\mathrm{Mg}_{2} \mathrm{Si}$ particles. Figure $2 \mathbf{f}$

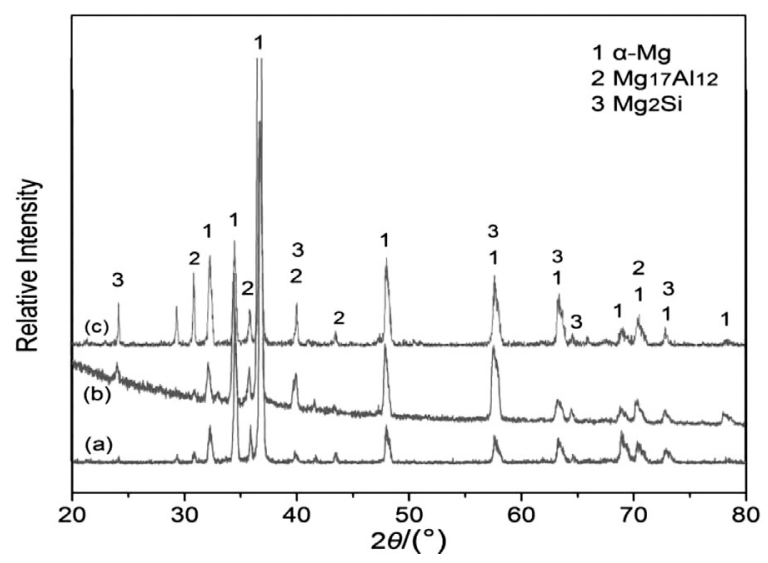

Figure 1: XRD patterns of studied Mg-Al-Si alloys: a) Mg-9 \% Al-0.3 $\% \mathrm{Si}$, b) Mg-9 \% Al-1.3\% Si, c) Mg-9 \% Al-2.3\% Si shows a typical higher-magnification image of the coarse Chinese-script-shaped $\mathrm{Mg}_{2} \mathrm{Si}$ and its size is larger than $28 \mu \mathrm{m} \times 80 \mu \mathrm{m}$. After the Si content is increased further to $2.3 \%$, a composition beyond the $\mathrm{Mg}-\mathrm{Mg}_{2} \mathrm{Si}$ binary eutectic composition of $1.36 \% \mathrm{Si}$ is formed where dendritic primary $\mathrm{Mg}_{2} \mathrm{Si}$ crystals are precipitated predominantly inside the grains. The largest dimension of the $\mathrm{Mg}_{2} \mathrm{Si}$ crystal is approximately $25 \mu \mathrm{m} \times 35 \mu \mathrm{m}$ and the $\mathrm{Mg}_{17} \mathrm{Al}_{12}$ eutectic is distributed continuously around the primary phases. In addition, the quantitative measured volume fraction of $\mathrm{Mg}_{2} \mathrm{Si}$ particles in $\mathrm{Mg}-9 \% \mathrm{Al}-\mathrm{x} \% \mathrm{Si}$ $(x=0.3,1.3,2.3)$ alloys are about $3.2 \%, 10.1 \%$ and $7.8 \%$, respectively.

The formation of $\mathrm{Mg}_{2} \mathrm{Si}$ crystals in $\mathrm{Mg}$-Al-Si alloys is affected greatly by the level of $\mathrm{Si}$ addition and the freezing conditions (the cooling conditions are identical for the studied alloys). Moreover, the growth rate of the $\mathrm{Mg}_{2} \mathrm{Si}$ particles is mainly controlled by solute-diffusion. Under a high degree of super cooling, the $\mathrm{Mg}_{2} \mathrm{Si}$ den- (a)
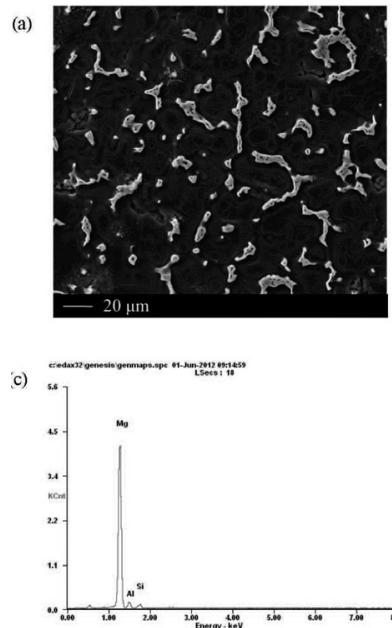

(e)
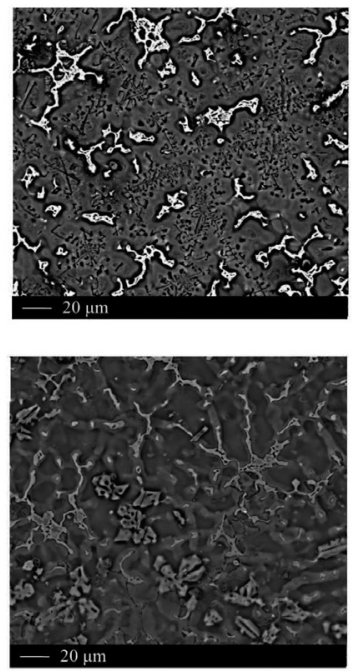

(b)

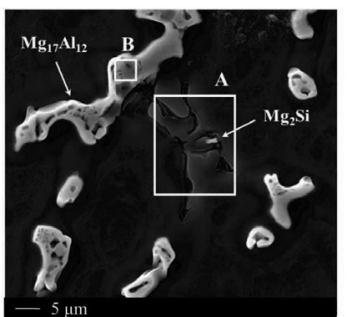

(d)

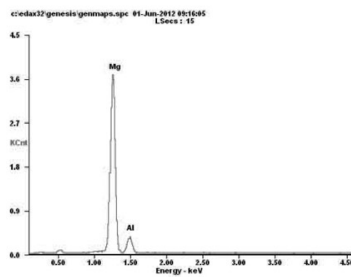

(f)

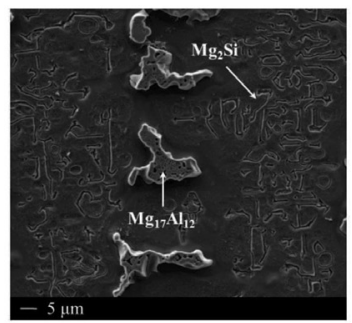

(h)

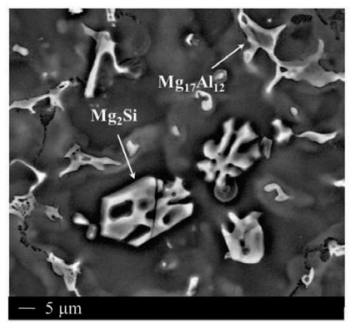

Figure 2: SEM images of studied Mg-Al-Si alloys: a) lower magnification of Mg-9 \% Al-0.3\% Si, b) higher magnification of Mg-9\% Al-0.3\% Si, c) EDS spectrum of area A, d) EDS spectrum of area B, e) lower magnification of Mg-9 \% Al-1.3\% Si, f) higher magnification of Mg-9 \% Al-1.3 \% Si; g) lower magnification of Mg-9 \% Al-2.3\% Si and h) higher magnification of $\mathrm{Mg}-9 \% \mathrm{Al}-2.3 \% \mathrm{Si}$ 
drites continuously grow into the melt because the atoms migrate rapidly on the freezing interfaces but diffuse relatively slowly in the melt. ${ }^{9}$ Thus, the solidification pathway in the studied alloys can be understood as follows. In the Mg-9\% Al-0.3\% Si alloy, fine $\mathrm{Mg}_{2} \mathrm{Si}$ eutectic precipitates at grain boundaries due to the segregation of atoms at the liquid-solid interface and inhibit the continuous precipitation of $\mathrm{Mg}_{17} \mathrm{Al}_{12}$ eutectics. The growth of the $\mathrm{Mg}_{2} \mathrm{Si}$ particle will also be limited as the level of $\mathrm{Si}$ addition is insufficient. After the Mg-9 \% Al-1.3\% Si alloy is poured into the mild steel mould, fine Chinese-script-shaped $\mathrm{Mg}_{2} \mathrm{Si}$ precipitates are prone to growing into a network consisting of coarse Chinese-script microstructures as the high cooling rate and $\mathrm{Si}$ content are provided. In this case the liquid phase between the Chinese script $\mathrm{Mg}_{2} \mathrm{Si}$ dendrites becomes enriched with $\mathrm{Al}$ atoms due to the rejection of Al solute atoms. Consequently, the $\mathrm{Mg}_{17} \mathrm{Al}_{12}$ eutectic precipitates locally as part of the final solidification process. In the Mg-9\% Al-2.3\% Si alloy, dendritic primary $\mathrm{Mg}_{2} \mathrm{Si}$ crystals would form preferentially. When the temperature cools to the $\mathrm{Mg}$-Si eutectic temperature, it is thermodynamically and kinetically preferential for the eutectic $\mathrm{Mg}_{2} \mathrm{Si}$ to nucleate and grow on the surface of the first precipitate in the $\mathrm{Mg}$-Al-Si alloy. ${ }^{9}$ As such no Chinese-script eutectic is observed. In addition, as the $\mathrm{Mg}_{2} \mathrm{Si}$ particles develop, the liquid phase surrounding them is enriched with $\mathrm{Al}$ solute atoms and precipitate $\mathrm{Mg}_{17} \mathrm{Al}_{12}$ phases continuously.
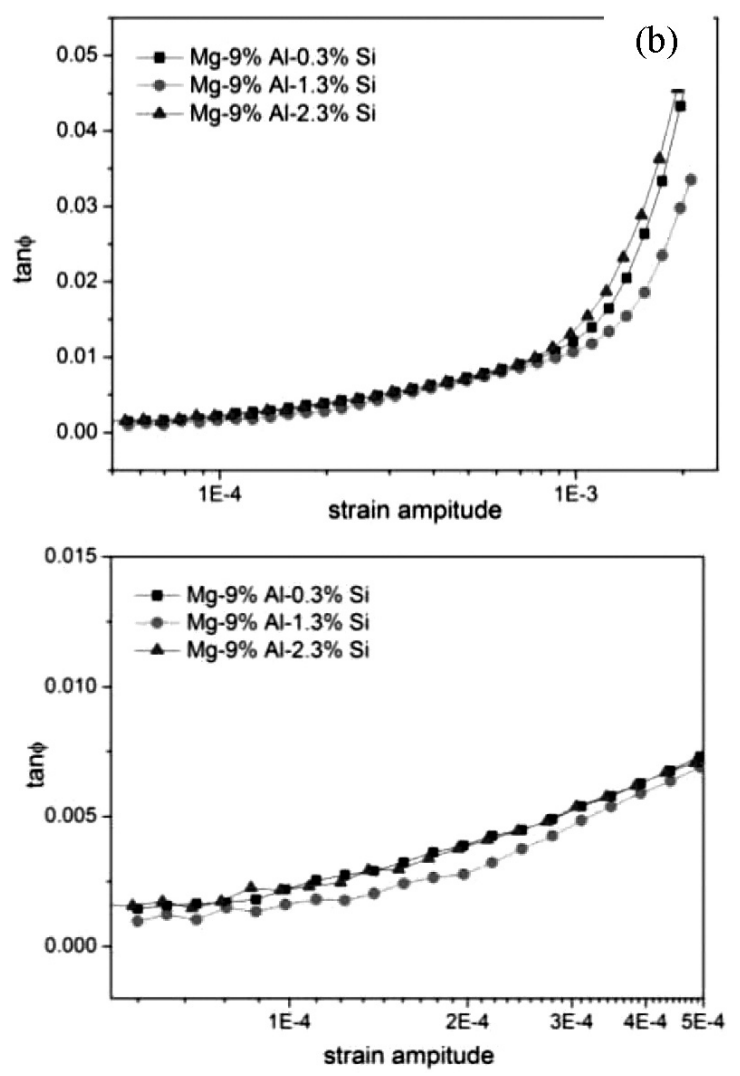

Figure 3: Damping capacities of Mg-Al-Si alloys: a) damping-strain amplitude curves, b) damping capacities at low strain amplitude
Figure 3 displays the damping capacities of the $\mathrm{Mg}-\mathrm{Al}-\mathrm{Si}$ alloys as a function of the strain amplitude. As shown in Figure 3a, all of the damping curves can be divided into two clear parts: the first part in the lower strain range, the strain amplitude has little influence on the damping properties. However, in the second part, after the strain amplitude reaches a certain value, the damping values increase rapidly with rising strain amplitude. A further detailed comparison of the low strainamplitude damping between the three alloys is illustrated in Figure 3b. It is clear that the Mg-9 \% Al-0.3\% Si and Mg-9\% Al-2.3\% alloys show better damping characteristics than the Mg-9 \% Al-1.3\% Si alloy. While at high strain stage, the Mg-9 \% Al-2.3\% Si alloy exhibits the highest damping value among the three Mg-Al-Si alloys.

The Granato-Lücke (G-L) mechanism is a wellaccepted theory that explains the damping mechanism by dislocations in $\mathrm{Mg}$ alloys. ${ }^{10,11}$ According to the G-L dislocation pinning model, the damping capacity can be divided into a strain-amplitude that is weakly dependent and one that is strongly dependent. The value of the strain-weakly damping is proportional to the dislocation density and the average distance between the weak pinning points of dislocations, and the strain-strongly dependent damping is critical to the dislocation density and the average dislocation distance between the strong pinning points. In addition, high dislocation densities at the interface of the particle-matrix, generated due to the thermal mismatch strain caused by the difference of CTEs of the metal matrix and the hard brittle reinforcing phase, are related to the size and geometry of the reinforcement particles. ${ }^{12,13}$ The dislocation density can be calculated using the prismatic dislocation-punching model of Arseault and Shimodle, ${ }^{14}$ which is expressed as follows in Equation (1):

$$
\rho_{\text {th }}=\frac{B \Delta \alpha \Delta T V_{\mathrm{f}}}{b t\left(1-V_{\mathrm{f}}\right)}
$$

where $B$ is a geometric constant, $b$ is the Burgers vector, $\Delta \alpha$ is the difference between the TECs of the reinforcement and the matrix, $V_{\mathrm{f}}$ is the volume fraction of the reinforcement, $\Delta T$ the temperature difference, and $t$ is the dimension of the reinforcement.

Given the dimension of the three types of $\mathrm{Mg}_{2} \mathrm{Si}$ (fine Chinese-script-shaped, coarse Chinese-script-shaped and dendritic crystals) in the $\mathrm{Mg}-\mathrm{Al}-\mathrm{Si}$ alloys, it can be inferred that each fine Chinese script $\mathrm{Mg}_{2} \mathrm{Si}$ crystal could generate a much higher dislocation density than another two kinds of particle, and the coarse Chinese-script structures can contribute least to the dislocation increase. Moreover, the quantity of these $\mathrm{Mg}_{2} \mathrm{Si}$ phases would influence the total dislocation density tremendously, the more $\mathrm{Mg}_{2} \mathrm{Si}$ particles precipitated, the more dislocations are observed. It is also worth pointing out that increasing $\mathrm{Si}$ content might not enhance the quantity of $\mathrm{Mg}_{2} \mathrm{Si}$ particles linearly. Take the Mg-9 \% Al-1.3\% Si alloy as an example, each coarse Chinese script $\mathrm{Mg}_{2} \mathrm{Si}$ consumes a large amount of Si atoms, so even after the Si addition 


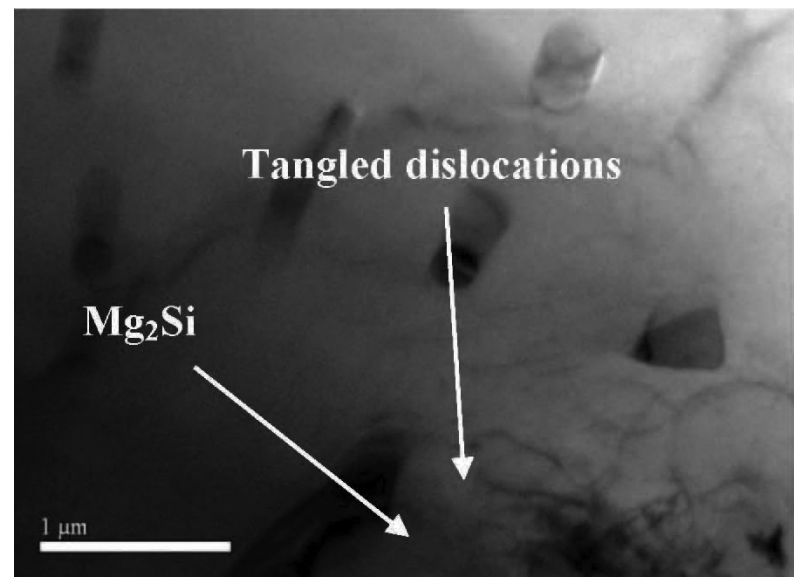

Figure 4: TEM image of dislocation configurations in Mg-9 \% Al-1.3 $\% \mathrm{Si}$

increases from $0.3 \%$ to $1.3 \%$, the number of $\mathrm{Mg}_{2} \mathrm{Si}$ particles does not show an obvious increase. Thus, taking both the amount and morphology of $\mathrm{Mg}_{2} \mathrm{Si}$ phase into account, we infer that the dislocation density in the $\mathrm{Mg}-9$ $\% \mathrm{Al}-1.3 \% \mathrm{Si}$ alloy would be lower than in the Mg-9 \% Al-0.3 \% Si and Mg-9 \% Al-2.3\% Si alloys, resulting in the lowest damping values among the three $\mathrm{Mg}-\mathrm{Al}-\mathrm{Si}$ alloys at low strain amplitude.

Under high strain amplitude, the shape and proportion of $\mathrm{Mg}_{2} \mathrm{Si}$ particles as well as the distribution of $\mathrm{Mg}_{17} \mathrm{Al}_{12}$ eutectic have a significant effect on the damping capacity. After the $\mathrm{Si}$ addition is increased to $1.3 \%$ from $0.3 \%$, fine Chinese-script $\mathrm{Mg}_{2} \mathrm{Si}$ eutectics grow into coarser ones. This transformation increases the amount of dislocation segments greatly and decreases the dislocation density, resulting in a reduction of the damping property. Figure 4 shows a transmission electron microscope picture of the dislocation configurations in the Mg-9\% Al-1.3\% Si alloy, it can be seen that the dislocation lines are tangled in the vicinity of $\mathrm{Mg}_{2} \mathrm{Si}$, which implies an inferior damping property. After the Si content adds to $2.3 \%$, the introduction of coarser $\mathrm{Mg}_{2} \mathrm{Si}$ particles would bring more hard pinning points compared with the Mg-9 \% Al-0.3\% Si alloy, but much less dispersed $\mathrm{Mg}_{17} \mathrm{Al}_{12}$ particles are observed in the alloy. As a result, the damping characteristic of the $\mathrm{Mg}-9$ $\%$ Al-2.3 \% Si alloy shows an improvement compared with another two $\mathrm{Mg}-\mathrm{Al}-\mathrm{Si}$ alloys at high strain range.

\section{CONCLUSIONS}

The morphology of $\mathrm{Mg}_{2} \mathrm{Si}$ phase is found to be a

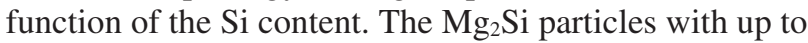
$1.3 \% \mathrm{Si}$ have a Chinese-script shape, and the dendritic $\mathrm{Mg}_{2} \mathrm{Si}$ crystals are precipitated predominantly inside the grains of the $2.3 \%$ Si-containing alloy. The morphology and volume of the $\mathrm{Mg}_{2} \mathrm{Si}$ particles as well as the distribution of $\mathrm{Mg}_{17} \mathrm{Al}_{12}$ eutectic have a significant effect on the damping capacities of the Mg-Al-Si alloys. In low strain amplitude, the dislocation density increases due to the formation of $\mathrm{Mg}_{2} \mathrm{Si}$ phases improving the damping property. Whilst in the high strain region, dispersed $\mathrm{Mg}_{17} \mathrm{Al}_{12}$ precipitates and coarse $\mathrm{Mg}_{2} \mathrm{Si}$ dendrites lead to a decrease in the internal friction values.

\section{REFERENCES}

${ }^{1}$ S. H. Baik, High damping Fe-Mn martensitic alloys for engineering applications, Nuclear Engineering and Design, 198 (2000) 3, 241-252, doi:10.1016/S0029-5493(99)00268-X

${ }^{2}$ D. Q. Wan, Strain amplitude-dependent internal friction of as-cast high damping magnesium alloy during cyclic vibration, Rare Metals, 32 (2013) 1, 25-28, doi:10.1007/s12598-013-0023-3

${ }^{3}$ X. L. Hou, Y. Li, P. Lv, J. Cai, L. Ji, Q.F. Guan, Hot deformation behavior and microstructure evolution of a Mg-Gd-Nd-Y-Zn alloy, Rare Metals, 35 (2016) 7, 532-536, doi:10.1007/s12598-015-0507-4

${ }^{4}$ M. Wang, D. H. Xiao, W. S. Liu, Effect of Si addition on microstructure and properties of magnesium alloys with high $\mathrm{Al}$ and $\mathrm{Zn}$ contents, Vacuum, 141 (2017), 144-151, doi:10.1016/j.vacuum. 2017.04.005

${ }^{5}$ S. Candan, E. Candan, S. Candan, E. Candan, A comparative study on corrosion of Mg-Al-Si alloys, Transactions of Nonferrous Metals Society of China, 27 (2017) 8, 1725-1734, doi:10.1016/S10036326(17)60195-X

${ }^{6}$ L. H. Liao, X. Q. Zhang, X. F. Li, H. W. Wang, N.H. Ma, Effect of silicon on damping capacities of pure magnesium and magnesium alloys, Materials Letters, 61 (2007) 1, 231-234, doi:10.1016/ j.matlet.2006.04.038

${ }^{7}$ X. S. Hu, K. Wu, M. Y. Zheng, W. M. Gan, X.J. Wang, Low frequency damping capacities and mechanical properties of $\mathrm{Mg}-\mathrm{Si}$ alloys, Materials Science and Engineering: A, 452-453 (2007), 374-379, doi:10.1016/j.msea.2006.10.099

${ }^{8}$ Q. C. Jiang, H. Y. Wang, Y. Wang, B. X. Ma, J. G. Wang, Modification of $\mathrm{Mg}_{2} \mathrm{Si}$ in $\mathrm{Mg}-\mathrm{Si}$ alloys with yttrium, Materials Science and Engineering: A, 392 (2005) 1-2, 130-135, doi:10.1016/ j.msea.2004.09.007

${ }^{9}$ L. Liao, X. Q. Zhang, H. W. Wang, X. F. Li, N. H. Ma, The characteristic of damping peak in Mg-9Al-Si Alloys, Journal of Alloys and Compounds, 429 (2007) 1-2, 163-166, doi:10.1016/ j.jallcom.2006.04.020

${ }^{10}$ R. Ma, X. P. Dong, B. S. Yan, S. Q. Chen, Z. B. Li, Z. Pan, H. J. Ling, Z. T. Fan, Mechanical and damping properties of thermal treated $\mathrm{Mg}-\mathrm{Zn}-\mathrm{Y}-\mathrm{Zr}$ alloys reinforced with quasicrystal phase, Materials Science and Engineering: A, 602 (2014), 11-18, doi:10.1016/j.msea.2014.02.055

${ }^{11}$ S. Chen, X. P. Dong, R. Ma, L. Zhang, H. Wang, Z. T. Fan, Effects of $\mathrm{Cu}$ on microstructure, mechanical properties and damping capacity of high damping $\mathrm{Mg}-1 \% \mathrm{Mn}$ based alloy, Materials Science and Engineering: A, 551 (2012), 87-94, doi:10.1016/j.msea.2012.04.098

${ }^{12}$ A. Granato, K. Lücke, Theory of mechanical damping due to dislocations, Journal of Applied Physics, 27 (1956), 583-593, doi:10.1063/1.1722436

${ }^{13}$ A. Granato, K. Lücke, Application of dislocation theory to internal friction phenomena at high frequencies, Journal of Applied Physics, 27 (1956), 789-805, doi:10.1063/1.1722485

${ }^{14}$ L. H. Liao, H. W. Wang, X. F. Li, N. H. Ma, Research on the dislocation damping of $\mathrm{Mg}_{2} \mathrm{Si} / \mathrm{Mg}-9 \mathrm{Al}$ composite materials, Materials Letters, 61 (2007) 11-12, 2518-2522, doi:10.1016/j.matlet.2006. 09.049 